\title{
COMMUNITIES OF PRACTICE FOR INDEPENDENT LEARNING PRACTITIONERS AT CAPABLE NZ, OTAGO POLYTECHNIC
}

\author{
Steve Henry, Kelli Te Maihāroa, John Gualter, David Woodward, \\ Robyn Hogan and Martin Andrew
}

\section{CONTEXT AND BACKGROUND}

This paper explores a range of face-to-face and online communities of practice (CoP) that are used to support groups of learners or mentors at degree and diploma levels using Independent Learning Programmes at Otago Polytechnic's Capable NZ. The six writers each create a narrative linking the purpose of specific CoPs to their observable outcomes. The narratives demonstrate such CoP features as mutual engagement, joint enterprise and shared repertoire. The value of the CoPs, over and above uniting colleagues in times of disruption, is outlined in each narrative of practice.

Ahi kā ki uta, ahi kā ki tai, kia horahorahia, purapura o ahi kā | Let your home fires be seen inland, let your home fires be seen along the coast, and may the sparks from your fires rise up and be seen throughout the world.

Capable NZ is a college of work based-learning within Otago Polytechnic, New Zealand. Established as the Centre of Recognition of Prior Learning, one key focus is to work with experienced candidates who gain qualifications through an Independent Learning Pathway (ILP) which uses prior experiences to frame new learning through reflection. Ker (2017) interviewed graduates, concluding that many Capable NZ learners benefit from engagement in communities of practice in their professional contexts (Ker, 2017). It is logical, then, for community of practice pedagogies, with their capacity to embed resilience in times of disruption (Andrew, 2020, forthcoming), to inform the learner experience. Malcolm (2020, this issue) describes their value in one such programme, the Bachelor of Leadership for Change. In such contexts of work-based learning, where learning from reflecting on, in and for practice is key (Schön, 1987), CoPs become valuable sites for the exploration of facets of learning and teaching from practice for both learners and for their mentors.

This enquiry unites six narratives of practice, using the method of storytelling as narrative practice to explore the meaningfulness and value of CoPs to learners completing their independent learning programmes and mentors engaged in sharing their experiences of practice in action, aiming to maximise learner socialisation and contribution and provide cushioning for reflection-led pivoting in response to the unpredictable. The stories were collected in response to the question "How do programmes in which you teach utilise communities of practice?," and curated as an anthology of separate stories of practice.

Communities of practice function as spaces of situated learning - that is, learning in context and in practice characterised by three main features which Wenger (1998) defined as mutual engagement, joint enterprise and shared repertoire. Members' senses of belonging come from their abilities to engage in activities for their own benefit and for the benefit of the group at its broadest level, and also from the shared nature of their objectives 
and the discourse (repertoire) of the community. This means that everyone can make a contribution which might help others; at the same time, the shared experiences and wisdoms of group members can increase expertise across the group.

In successful CoPs, there is a balance of benefit for both the community and its individuals (Andrew, 20I4) and a sense of the more novice members reaching learning goals through legitimate peripheral participation (Lave \& Wenger, 1991). Lave and Wenger envisage a CoP as a series of concentric circles, with the target knowledge and repertoire situated in an innermost circle, those considered to be the 'experts.' Participating peripherally are the learners, who learn by a process of observation that becomes increasingly participative with time and the building of trust. CoPs in contexts involving stakeholders in independent pathways, then, are places that value the trajectories of both novice and experienced learner.The joint enterprise of all members becomes shared capital through the act of sharing repertoire, which, in this article, take the form of narratives of practice.

The first narrative, contributed by by Kelli Te Maihāroa, examines the value of an iwi-led CoP approach at Te Kāhui Whetū (Capable Māori) within a Bachelor of Applied Management. Next, John Gualter unfurls the value of CoPs to the story of cohorts within the National Diploma in Building Control Surveying and Bachelor of Applied Management (or BAM) in a defence force context and demonstrates the capacity for response to the unexpected. Thirdly, Robyn Hogan describes the emergent community activity of the Bachelor of Social Services CoP.The final three stories are situated within postgraduate programmes: David Woodward explores the work of the learning community within the Graduate Diploma in Tertiary Education; Steve Henry opens out the practices of the graduate programmes in which he operates; and Martin Andrew enters the shared mentoring community spaces of the Doctorate in Professional Practice.

\section{NARRATIVE I: IWI-LED COMMUNITIES OF PRACTICE}

Te Kāhui Whetū | Capable Iwi Māori is a kaupapa Mãori whānau, aligned with the principles of the CoP, within Capable NZ, tailored for those who live and practice tikaka Māori and the hapū, iwi and Māori organisations that support them. It offers a suite of programmes from bachelor degrees to postgraduate qualifications, made accessible for Iwi Māori and offering a kaupapa Māori learning environment.

The iwi-led CoP offers a range of affordances, as observed in the repertoire of our community. There is a culture of learning collectively, working with whānau who share a Māori world view and whānau-based values. Further, learners report feeling safe within a culturally responsive, strength-based learning environment. This safety is a function of the building of trust, a characteristic of effective CoPs, and also stems from the fact that learners use their knowledge of Māori models, values, beliefs, community, whānau, hapū, iwi and hāpori, honouring their tohu. Hence, the repertoire they share is valuable for its community-building effect, and also for affirming individuals' journeys. Led by iwi, community members learn with the support and encouragement of iwi leaders, unique and distinct to learners' rohe. This identity-affirmative pedagogy enables learners to take part, when appropriate, in collective presentations and assessments and, ultimately, to celebrate collectively with a Māori pre-graduation ceremony. The collectivity of this iwi-led approach, emphasising the ako inherent in CoPs, mirrors the strengths of the CoP.

This narrative has at its heart a success story. This success is the result of learners' efforts, along with those of the initial kaupapa Māori team. Te Kāhui Whetū is now able to offer Kāi Tahu facilitators delivering this innvoative programme to, with and for Kāi Tahu whānui: for Kāi Tahu, with Kāi Tahu, by Kāi Tahu. A partnership between Te Rūnanga o Ngāi Tahu and Otago Polytechnic has supported three Te Hōkai Nui whānau cohorts in 20 I 4, 2016 and 2018 .

The iwi-led CoP has proven invaluable. Between 2014 and 20I8, Te Hōkai Nui had a 96 percent success rate in the Bachelor of Applied Management, with 59 graduates, 31 distinctions and 17 learners expressing an interest in studying for a Masters of Professional Practice. In 2020, Te Kāhui Whetū had the largest iwi cohort to date, with 28 Kāi Tahu whānui learners expected to graduate in May 2021. Te Kāhui Whetū has its own Community of Practice 
with Iwi Māori across Aotearoa, with a determined focus on unleashing and realising Māori potential through the leveraging of learners' mutual engagements and shared enterprise and repertoire.

\section{NARRATIVE 2: CHALLENGES TO MAINTAINING COMMUNITY INTHE NATIONAL DIPLOMA IN BUILDING CONTROL SURVEYING AND THE BACHELOR OF APPLIED MANAGEMENT}

The first part of this narrative outlines the challenges to maintaining the unity of geographically scattered cohorts as communities of practice within the National Diploma in Building Control Surveying. Although most learners are male, the learner cohort comprises a challenging demographic: learners are aged from 21 to 69 and are at different career stages.

The first challenge was the need to move to cloud-based submissions via google drive. Taking a CoP approach to cohort management mitigated the problem, as late or resistant adopters of technology were mentored by confident participants. This enabled otherwise peripheral participants access to the shared discourse and practice of the cohort.

Geographical spread afforded the second challenge.The groups were spread throughout New Zealand, and Capable $\mathrm{NZ}$ agreed to ensure consistency of shared repertoire by enabling facilitators to travel to the learners. For each of these cohorts, based on the various councils they worked for, facilitators met learners face-to-face for an initial twoday workshop, followed up by another workshops six months later. The sharing of the repertoire of the CoP moved to e-modes: phone, skype and email consultation with individuals. The fact that the discourse was shared in a single cloud-based site, representative of the CoP, ensured consistency of messaging and sharing of repertoire. This model also allowed the sharing of portfolios with assessors prior to assessment without the need for couriering portfolios nationally. Clearly, agility and flexibility were essential to messaging and sharing in this CoP.

The narrative now moves to how CoP pedagogy mitigates challenges for cohorts in the Bachelor of Applied Management for the Royal New Zealand Air Force, where a unique 18-month programme, revolving around an indepth work-based project, has been delivered since 2004. Traditionally facilitated by a two-day initial workshop, with two more workshops over the following 18 months, the programme is completed using a unifying cloud-based site of sharing repertoire. This resource system facilitates monitoring and mitigates any issues in advance. It comprises a google resource repository of a life's experience of learnings and information, shared with each learner. Other tools of the online CoP, a private Facebook group page and messenger group, allowed group discussion and the sharing of repertoire during the period of the qualification.

This CoP-based methodology has been implemented with all individual learners and cohorts over the past eight years: approximately 400 learners with the NZ Defence Force and Navy and the Building Control Industry Training Organisation. In essence, it is a framework that can be adjusted to suit the varying composition and needs of each cohort and the needs of individuals within them.

\section{NARRATIVE 3: COMMUNITY INTHE BACHELOR OF SOCIAL SERVICES}

This community was a very loosely defined group of practitioners who worked in supervisory roles and in training and policy development in a government organisation charged with social responsibility. The CoP has been self-organising since 20 0: after an initial five-day intensive with learners and mentors, learners are invited to join the CoP.

The various professional roles within the group and the nature of those roles meant that the day-to-day professional lives of many of the members was not routine: members could be called away from their desk at a moment's notice. Stress levels were high. Membership changes erratically and regularly. For these reasons, routine meetings were not an option. 
Community-building, with the experienced supporting the novice, grew out of a desire to enable understanding of what those at the coalface are experiencing; what they need; what needs to change at national level. It developed as a collaborative model rather than an ego-driven, competitive one. It came together informally and in response to the desire of individuals to develop their understanding through other practitioners' unique knowing. The CoP developed organically over time; it was not an entity that was intentionally set up from the get-go. Within the developing CoP, some members have taken on the role of non-judgemental peer-mentors. Here we see Lave and Wenger's (1991) legitimate peripheral participation leveraged to maximise interaction and learning opportunities.

Group membership has changed over time, but also expanded in numbers. Although there are still no collective formal meetings, smaller groups and individuals within the larger group meet and communicate intermittently, then share their experiences and any new understanding and thinking with others. It has the voice of the expert, the practitioner and the learner. The community is held together by the common purpose of thinking together and indirectly sharing tacit knowledge. Once more, the concepts of mutual engagement, joint enterprise and shared repertoire underpin the creation and development of the CoP.

\section{NARRATIVE 4: BUILDING COMMUNITY INTHE GRADUATE DIPLOMA INTERTIARY EDUCATION}

In 2019, a group of recent Graduate Diploma in Tertiary Education graduates, representing both the taught Recognition of Prior Learning (RPL) and Independent Learning Pathway (ILP) programmes at Otago Polytechnic $(\mathrm{OP})$, was brought together as a CoP to collaborate on producing a paper in April 2019. The catalyst for this article was the 2018 Capable NZ Professional Practice Symposium, where examples of Teaching Philosophy Statements and the process utilised to prepare them was discussed (Woodward, Hegarty, Allen, \& Redfearn, 20 I 8). The audience was introduced to the use of metaphor and established frameworks, such as those developed by Chism (1998) and Schönwetter, Sokal, Friesen and Taylor (2002), for structuring Teaching Philosophy Statements. The aim of the CoP, established by Woodward and Hegarty, was to articulate the process of developing a model of professional teaching practice expressed through the Teaching Philosophy Statement, illustrating how this can provide evidence for a tertiary teaching credential. Eight lecturers met regularly on skype. The CoP developed a research paper (Woodward et al., 2019) and presented symposia. These works represent the shared repertoire of the community.

The value of the CoP was, through critical reflection, to provide a rich environment for teaching practitioners to discuss and share ideas about teaching philosophies, helping them to develop a meaningful statement of teaching practice (Woodward et al., 2019). As a result, the CoP has continued in 2020, with six Otago Polytechnic lecturers, as a forum for exchange of ideas between like-minded tertiary teaching professionals on teaching pedagogy and to examine the importance of developing evidence-based teaching practice.

The aim is to determine some of the key theories and models that inform pedagogical practice and to look at how these theories link to teaching practice in teachers' own areas of specialisation, culminating in further sharing of the community's output, which has the added value of bringing multiple members into researcher identities. The future potential value of the CoP is to continue to mine information from like-minded teaching practitioners who may not normally be involved in research, providing outputs of research papers and presentations at future symposiums. Building individual identities grounded in joint enterprise through the sharing of activity and repertoire is core capital of successful CoPs (Andrew, 20I4).

\section{NARRATIVE 5: EXPERIENCES OF GRADUATE COMMUNITIES}

The Graduate Diploma in Sustainable Practice and Graduate Diploma in Professional Practice-Sustainable Practice mix taught and independent learners in a Community of Practice that meets weekly in an online class to share their learning. There are usually eight to ten learners in a meeting. Learners come from a range of disciplines and share 
using frameworks which become a common language - the Wengerian "shared repertoire." As learners become skilled in a shared language of success in social, economic and ecological terms, this success enables access to technical perspectives that might otherwise have excluded them because of jargon. Learning to collaborate is a key capability in sustainable practice, so a community of practice is an enabler of this.

In 2019 , embedded in the emerging CoP within the Masters of Professional Practice, five 90-minute video conference sessions were held for groups of current learners and alumni to share their learning experiences in and since the programme. Nineteen individuals attended the sessions.

The value for those attending was discussed at the end of each session, and the single theme that emerged was the value of unexpected insights gained by sharing with peers what is otherwise an independent learning journey. Engaging with others who have limited understanding of each other's professions means that the use of jargon to describe practice has to be avoided. The true sharing of repertoire requires clarity of discourse, and the language of the CoP marks it as a discourse community. The desire to draw the community together through a common language to articulate their work not only benefits both the community and individuals within it, but also fosters belonging and builds trust by reducing the threat posed by jargonese. One current learner said: "Describing my work to others who knew nothing of it made me realise I was not able to be clear. As a result of this insight, I radically changed the focus of my work."

\section{NARRATIVE 6:THE WORK OFTHE DOCTORATE IN PROFESSIONAL PRACTICE COP}

The Community of Practice of mentors in the Doctorate of Professional Practice (DPP) was created in 2020 to enable all experienced and less experienced mentors to share a space of mutual engagement, joint enterprise and shared repertoire. It arose from the fact that the activities and practices of mentoring in the transdisciplinary spaces of a professional doctorate differed from those of traditional doctorate models, where research is seen as a linear process, almost independent of its writer, fostered by a process of supervision, with the expert sagely leading the student. The locus of power in this community of practice is distributed, and all participants bring their experiences and perceptions to the community. The practices of DPP mentors are discussed, analysed and shared. Meetings happen approximately three times every two months, with sufficient regularity to sustain the energy of the group.

The CoP comprises all people registered as mentors of one or more learner on the DPP, and the membership on paper is as high as 40. As a person experienced in mentoring across all doctorate models, and as a contractor with 14 DPP learners, Martin Andrew was appointed to create and lead the group. The first task was to negotiate a programme of learning based on needs identified by the group and implied by the demands of the programme and data collected by Capable NZ, who run the programme. Amongst the shared repertoire to date have been stories of coping with data collection in an age of Covid-19; shared stories of developing practice; and clarification of how a DPP journey differs from that of other doctorate forms.

Through this CoP, mentors share knowledge, experience, practice, hopes and expectations. It is a space of learning and aims for a distributive power structure with a facilitative leadership. It aims to build trust and desire for membership by drawing on individuals' shared goals and values and overlapping life histories. Its particular value is for the novice, but all members benefit from participating in a site of belonging. We can all learn from the stories and expertise of others. Ultimately, the DPP CoP is a place where 'novices' come closer to the 'core' by understanding and participating in the mutual engagement and shared repertoire of the group.

\section{CONCLUSIONS:THEVALUE OF COPS}

While the short narratives collected above do not constitute case studies, it is clear that the adoption and maintenance of CoPs within an organisation characterised by Independent Learning Programmes brings added value for learners, as well as providing a context for resilient teaching and learning. Although the study did not explicitly 
investigate the link between CoP pedagogy and independent learning pathways, there is evidence that learning in CoPs results in better sharing of enterprise and enhances the reflectivity that is a precursor of independent learning.

In addition to fostering individuals' trajectories of learning and hence identities, CoPs build trust, belonging and afford the sharing of repertoire, as in repositories, online discussions or shared reflections. Importantly, they draw on whānau-based values and align with kaupapa Māori methodologies of both teaching and research practice.

These stories suggest that mutual engagement can result in unexpected value and that learners who prefer social settings are encouraged in communities of practice. The narratives show, too, that there is value for both the novice and the experienced community members in sharing learning, and that a common mutually agreed language, free of jargon, can build group membership and facilitate communication and interaction. Appropriate power relations unify and encourage members within a CoP; and when it is optional to attend, then a measure of value is that the community operates organically of its own accord. Lastly, having a flexible approach to each individual learner/cohort that utilises the affordances of technology and the wide range of tools available enhances the learner experience and reduces inefficiencies for facilitators or mentors. Effectively, CoPs have the capacity to keep everyone on the same page. As Hung and Der-Thanq (200I) wrote: "People, forming a community, come together because they are able to identify with something - a need, a common shared goal and identity" (p. 3). Leveraging these needs and goals, our narratives begin to suggest, can foster valuable group and individual identities.

All the authors work at Capable NZ Otago Polytechnic as learning facilitators and academic mentors. Correspondence to info@capablenz.co.nz.

Andrew, M. (20I4). Community and individuality:Teaching and learning insights from a postgraduate online writing program. SAGE Open, 4(3), I-13. https://doi.org/ / 0.1 I 77/2158244014544292.

Andrew, M. (2020). Reflecting on then and now: Pedagogical being in lockdown via zoom. Collective Voices of COVID-19. Dunedin: Otago Polytechnic (forthcoming).

Chism, N.V. N. (1998). Developing a philosophy of teaching statement. Essays on Teaching Excellence, 9(3), I-2.

Hung, D., \& Der-Thanq, C. (200 I). Situated cognition,Vygotskian thought and learning from the communities of practice perspective: Implications for design of web-based e-learning. Educational Media International, 38(I), 3-12.

Ker, G. R. (2017). Degrees by Independent Learning: A case study of practice at Otago Polytechnic, Dunedin, New Zealand [Unpublished DProfStudies (Adult Learning) thesis]. Middlesex University, London, UK.

Lave, J. \& Wenger, E. (199I). Situated learning: Legitimate peripheral participation. Cambridge, UK: Cambridge University Press.

Malcolm, M. (2020). A self-determined learning environment supporting change-makers. Scope: Contemporary Research Topics (Workbased Learning) (this issue, forthcoming).

Schön, D. A. (1987). Educating the reflective practitioner:Toward a new design for teaching and learning in the professions. San Francisco, CA: Jossey-Bass.

Schönwetter, D. J., Sokal, L., Friesen, M., \& Taylor, K. L. (2002). Teaching philosophies reconsidered: A conceptual model for the development and evaluation of teaching philosophy statements. International Journal for Academic Development, 7(I), 83-97. http://dx.doi.org/10.1080/13601440210156501

Wenger, E. (1998). Communities of practice. Cambridge, UK: Cambridge University Press.

Woodward, D., Hegarty, B., Allen, E., \& Redfearn, S. (2018). Developing a teaching philosophy. Paper presented at Capable NZ Professional Practice Symposium: Exploring Professional Futures, I I December 20 I 8, Otago Polytechnic.

Woodward, D., Hegarty, B., Allen, E., Booth, S., Redfearn, S., Smith, S., Wakelin, K. \& Webster, J. (2019). Developing a teaching philosophy for a teaching credential. Scope: Contemporary Research Topics (Learning and Teaching), 7, 31-42. https://doi. org/l 0.34074/scop.4007005. 